\title{
PENGARUH PERSEPSI MAHASISWA AKUNTANSI MENGENAI LINGKUNGAN KERJA EKSTERNAL AUDITOR TERHADAP PILIHAN KARIRNYA SEBAGAI AUDITOR
}

\author{
Oleh : \\ Memen Kustiawan \\ (Dosen Program Studi Akuntansi Fakultas Pendidikan Ekonomi \& Bisnis UPI BHMN Bandung) \\ Iim Jaemah \\ (Alumni Program Studi Akuntansi Fakultas Pendidikan Ekonomi \& Bisnis UPI BHMN Bandung)
}

\begin{abstract}
Abstrak
Penelitian ini bertujuan untuk mengetahui pengaruh persepsi mahasiswa akuntansi mengenai lingkungan kerja eksternal auditor terhadap pilihan karimya sebagai auditor. Indikator variabel lingkungan kerja eksternal auditor yang digunakan mengacu pada instrumen yang dikembangkan oleh Dezoort et al (1997). Metode penelitian yang digunakan adalah metode deskriptif dengan pendekatan survey. Data yang terkumpul diperoleh melalui penyebaran kuesioner kepada mahasiswa akuntansi Universitas Pendidikan Indonesia angkatan 2004, 2005, 2006, kemudian untuk mengkaji hipotesis penelitian digunakan statistik non-parametrik dengan teknik koefisien kontingensi (C) yang berkaitan erat dengan teknik chi kuadrat $\left(\chi^{2}\right)$. Hasil penelitian menunjukkan bahwa persepsi mahasiswa akuntansi mengenai lingkungan kerja eksternal auditor memiliki pengaruh yang signifikan terhadap pilihan karimya sebagai auditor. Disamping itu, diketahui pula bahwa terdapat keterkaitan erat antara pilihan karir mahasiswa akuntansi sebagai auditor dengan persepsinya mengenai lingkungan kerja eksternal auditor. Dengan demikian, dapat disimpulkan bahwa persepsi mahasiswa akuntansi mengenai lingkungan kerja eksternal auditor turut berperan dalam proses pengambilan keputusan karimya sebagai auditor.
\end{abstract}

Kata kunci : Persepsi Mahasiswa Akuntansi, Lingkungan Kerja,Karir Auditor.

\section{Latar Belakang Penelitian}

Dalam proses pemilihan karir, setiap individu akan selalu mempertimbangkan segala potensi, bakat/minat, kecerdasaan maupun harapan yang akan dicapai. Pilihan karir merupakan suatu proses atau aktivitas individu dalam usaha mempersiapkan diri untuk memasuki karir yang berhubungan dengan pekerjaan melalui suatu rangkaian proses kegiatan yang terarah dan sistematis, sehingga mampu memilih karir sesuai dengan yang diinginkan.

Ada berbagai macam pilihan profesi dalam bidang akuntansi, salah satunya adalah auditor yang merupakan profesi akuntansi yang paling diminati oleh para mahasiswa akuntansi. Penelitian yang dilakukan oleh Sharon Ayumediaz (2005) mengenai persepsi mahasiswa akuntansi Universitas Padjajaran tentang lingkungan 
kerja auditor menunjukkan bahwa mahasiswa akuntansi memiliki persepsi positif tentang lingkungan kerja auditor cenderung memilih auditor sebagai pilihan karimya yaitu sebanyak $62 \%$ dari total responden. Sedangkan sisanya sebanyak $38 \%$ memilih karir non auditor sebagai pilihan karir.

Profesi auditor memiliki persepsi negatif yang berkaitan dengan turnover yang biasanya terjadi pada staf yang baru masuk. Rhode et al (1977) dalam penelitiannya tentang penyebab turnover profesi auditor menyatakan bahwa alasan yang paling banyak diberikan untuk meninggalkan profesi auditor adalah (1) Konflik antara kerja dengan kehidupan keluarga (2) Tersitanya terlalu banyak waktu (3) Ketidakmampuan individu yang bersangkutan untuk menggunakan bakat dan kemampuannya.

Carcello et al (1991) mengindikasikan atribut profesi auditorlah yang dapat mengurangi minat mahasiswa akuntansi untuk memilih karir sebagai auditor atau menyebabkan mereka yang sudah memilih auditor sebagai karir menjadi tidak puas. Empat karakteristik yang paling sering disebutkan adalah overtime, deadline/budget yang tidak realistis, stress/tekanan pekerjaan serta politik perusahaan. Dua dari karakteristik tersebut, yaitu overtime dan stress/tekanan pekerjaan, merupakan alasan yang paling banyak diberikan untuk meninggalkan profesi auditor.

Pilihan karir mahasiswa akuntansi sebagai auditor dimulai dengan mencari informasi dan mempertimbangkan sebagai karir altenatif yang ada pada saat mereka kuliah. Perkuliahan dapat membantu mahasiswa untuk mengenali sifat karir akuntansi dengan memberikan pengetahuan dan keterampilan yang diperlukan untuk sukses profesi akuntansi. Hal ini akan membantu mereka membuat pilihan profesi dengan latar belakang informasi yang baik.

Berbagai informasi yang diperoleh mahasiswa akuntansi mengenai profesi auditor merupakan hal yang penting dalam proses pengambilan keputusan karirnya sebagai auditor. Adanya informasi yang negatif mengenai lingkungan kerja auditor mungkin dapat mengurangi minat mereka untuk memilih karir sebagai auditor, dan mengalihkan pilihan karirnya pada profesi akuntansi yang lain. Dengan demikian, profesi auditor dapat kehilangan calon-calon auditor yang berkualitas.

\section{Rumusan Masalah}

Berdasarkan latar belakang yang telah diuraikan sebelumnya, rumusan masalah penelitian ini adalah :

1. Bagaimana persepsi mahasiswa akuntansi mengenai lingkungan kerja eksternal
auditor

2. Bagaimana pilihan karir mahasiswa akuntansi sebagai auditor

3. Apakah persepsi mahasiswa akuntansi mengenai lingkungan kerja eksternal auditor memiliki pengaruh terhadap pilihannya untuk berkarir sebagai auditor. 


\section{Kerangka Pemikiran}

Perencanaan karir sangat dipengaruhi oleh karakteristik individu tersebut, yang akan mempengaruhi bagaimana seseorang membuat pilihan karir. Bakat, minat, kelebihan dan kekurangan juga latar belakang sosial dalam diri seseorang merupakan faktor-faktor yang mempengaruhi dalam pemilihan karir.

Krech, Chuthfield dan Ballachey yang dikutip oleh Dewi Yanti Harahap (1998;33), pengertian pilihan karir adalah merupakan suatu usaha individu mempersiapkan diri untuk memasuki karir yang berhubungan dengan pekerjaan melalui serangkain proses kegiatan yang terarah dan sistematis, sehingga mampu memilih karir sesuai dengan yang diinginkan.

Berdasarkan penelitian yang dilakukan oleh Felton, et al (1994) dalam Andrianti (2001) yang dikembangkan oleh Kunartinah $(2003 ; 183)$ terhadap mahasiswa akuntansi menyatakan bahwa mahasiswa akuntansi dalam memilih karir dipengaruhi oleh lima faktor yaitu:

1) Faktor Intrinsik : faktor intrinsik pekerjaan memiliki hubungan kepuasan yang diterima oleh individu saat atau sesudah ia melakukan pekerjaan (job content). Faktor-faktor ini meliputi penghargaan kesempatan mendapat promosi, tanggung jawab pekerjaan, tantangan intelektual, pelatihan dan sebagainya.

2) Penghasilan Jangka Panjang dan Penghasilan Jangka Pendek

Penghasilan atau gaji yang diperoleh sebagai kontraprestasi dari pekerjaan telah diyakini secara mendasar bagi sebagian besar perusahaan sebagai daya tarik utama untuk memberikan kepuasan kepada karyawannya. Kompensasi financial yang rasional menjadi kebutuhan mendasar bagi kepuasan kerja.

3) Pertimbangan Pasar Kerja: Job Market Consideration yang digunakan dalam penelitian ini meliputi faktor jangka pendek seperti tersedianya pekerjaan dan faktor jangka panjang seperti keamanan kerja, fleksibilitas karir dan kesempatan promosi.

4) Latar Belakang Pendidikan di SMU (Sekolah menengah Umum): mahasiswa jurusan akuntansi akan cenderung memilih karir sebagai akuntan publik, apabila dia memiliki dasar pengetahuan (knowledge basic) tentang akuntansi yang memadai, yang diperoleh saat SMU dulu.

5) Persepsi Rasio Keuntungan dan Kerugian Menjadi Akuntan Publik : dalam berkarir menjadi akuntan publik, mahasiswa jurusan akuntansi akan berpikir tentang keuntungan dan kerugian memilih karir tesebut, sehingga rasio keuntungan dan kerugian menjadi akuntan publik mempengaruhi keputusan mahasiswa untuk memilih karir.

Dalam penelitian Dezoort et al (1997), lingkungan kerja auditor dijabarkan dalam 3 indikator yang dinilai cukup meliputi berbagai isu yang relevan dengan dunia akuntansi publik, yaitu:

1. Tugas dan tanggung jawab kerja

2. Promosi, pelatihan, dan pengawasan

3. Masalah pribadi

Mahasiswa mendapatkan informasi mengenai lingkungan kerja auditor dari berbagai media. Sumber-sumber utama mengenai lingkungan kerja auditor bagi 
mahasiswa diantaranya adalah buku kuliah, dosen, internet, jurnal penelitian, alumni, akuntan, media massa, keluarga, teman serta pengalaman kerja

Informasi yang diperoleh tersebut membentuk persepsi para mahasiswa mengenal lingkungan kerja auditor. Jalaludin Rakhmat $(1998 ; 51)$ menyatakan bahwa pengertian persepsi adalah "pengalaman tentang objek, peristiwa atau hubunganhubungan yang diperoleh dengan menyimpulkan informasi dan menafsirkan pesan".

\section{Metode Penelitian}

Metode penelitian yang digunakan dalam penelitian ini adalah metode deskriptif dengan pendekatan survey. Metode deskriptif menurut Moh. Nazir (2003:63) yaitu suatu metode untuk meneliti status sekelompok manusia, suatu objek, suatu sistem pemikiran ataupun suatu kelas peristiwa pada masa sekarang. Tujuan dari penelitian deskriptif ini adalah untuk membuat deskripsi, gambaran atau lukisan secara sistematis, faktual dan akurat mengenai fakta-fakta, sifat-sifat serta hubungan antar fenomena yang diselidiki.

Sedangkan pengertian metode survey menurut Moh. Nazir (2003:65) adalah Penyelidikan yang diadakan untuk memperoleh fakta-fakta dari gejala-gejala yang ada dan mencari keterangan-keterangan secara faktual, baik tentang institusi sosial, ekonomi atau politik dari suatu kelompok ataupun suatu daerah. Metode survey membedah dan menguliti serta mengenal masalah-masalah serta mendapatkan pembenaran terhadap keadaan dan praktik-praktik yang sedang berlangsung.

Tabel 1. Operasionalisasi variabel

\begin{tabular}{|c|c|c|c|}
\hline Variabel Penelitian & Dimensi & Indikator & Skala \\
\hline \multirow{11}{*}{$\begin{array}{l}\text { Persepsi mahasiswa } \\
\text { akuntansi mengenai } \\
\text { lingkungan kerja } \\
\text { auditor } \\
\text { (Dezoort dkk, 1997) }\end{array}$} & \multirow{2}{*}{$\begin{array}{l}\text { Tugas dan } \\
\text { tanggung } \\
\text { jawab kerja }\end{array}$} & $\begin{array}{l}\text { 1.Pengetahuan dan keahlian yg } \\
\text { dibutuhkan }\end{array}$ & \multirow{11}{*}{ Ordinal } \\
\hline & & $\begin{array}{l}\text { 2.Atribut dan manfaat profesi } \\
\text { auditor }\end{array}$ & \\
\hline & \multirow{3}{*}{$\begin{array}{l}\text { Promosi, } \\
\text { pelatihan, dan } \\
\text { pengawasan }\end{array}$} & $\begin{array}{l}\text { 1. Kemahiran pekerjaan pada } \\
\text { tahun pertama }\end{array}$ & \\
\hline & & $\begin{array}{l}\text { 2. Harapan atas pelatihan oleh } \\
\text { KAP }\end{array}$ & \\
\hline & & $\begin{array}{l}\text { 3. Harapan atas tingkat dan } \\
\text { kecukupan supervise kerja }\end{array}$ & \\
\hline & \multirow[t]{6}{*}{$\begin{array}{l}\text { Masalah } \\
\text { Pribadi }\end{array}$} & $\begin{array}{l}\text { 1. Standar etik dan interaksi } \\
\text { dengan rekan }\end{array}$ & \\
\hline & & $\begin{array}{l}\text { 2. Dukungan perusahaan dalam } \\
\text { persiapan USAP }\end{array}$ & \\
\hline & & 3. Harapan atas waktu lembur & \\
\hline & & 4. Jumlah perjalanan & \\
\hline & & 5. Harapan atas penugasan kerja & \\
\hline & & 6. Balas jasa & \\
\hline $\begin{array}{l}\text { Pilihan karir } \\
\text { mahasiswa akuntansi }\end{array}$ & Career plan & $\begin{array}{l}\text { a. Auditor } \\
\text { b. Non auditor }\end{array}$ & Nominal \\
\hline
\end{tabular}

Jurnal Akuntansi Riset, Prodi Akuntansi UPI, Vol. 1, No. 1 
Populasi yang digunakan dalam penelitian ini yaitu seluruh mahasiswa program studi akuntansi angkatan 2004, 2005 dan 2006. Metode sampling yang digunakan dalam penelitian ini adalah metode sampling non-probabilitas dengan teknik pengambilan sampel bertujuan (purposive sampling). Adapun rumus yang digunakan untuk menentukan besarnya ukuran sampel yang akan diteliti dalam penelitian ini adalah dengan menggunakan cara Slovin dengan taraf kesalahan 10\%. Dari perhitungan tersebut, didapatkan ukuran sampel yang dapat diambil dalam penelitian ini, yakni sebanyak 75 orang.

Teknik pengumpulan data yang dipergunakan penulis dalam penelitian ini adalah data primer yang didapat langsung dari lapangan dan data primer yang diperoleh dari instansi yang terkait. Untuk data primer, pengumpulan data dilakukan dengan cara survey dan observasi. Teknik pengumpulan data yang digunakan dalam penelitian ini adalah survey dengan teknik kuesioner.

\section{Hasil Penelitian}

Berdasarkan hasil pengujian validitas yang dilakukan terhadap butir-butir pernyataan dalam kuesioner untuk variabel persepsi mahasiswa akuntansi mengenai lingkungan kerja eksternal auditor, hampir seluruh butir pernyataan memiliki nilai thitung lebih besar dari nilai tabel 1,70 kecuali butir no 3 yaitu pernyataan mengenai diperlukan keahlian komunikasi yang baik, baik lisan maupun tulisan untuk sukses sebagai auditor. Dengan demikian sebanyak 27 butir pernyataan dinyatakan valid dan butir no 3 yang tidak valid harus dikeluarkan dari kuesioner dan tidak dipergunakan dalam penelitian.

Pengujian reliabilitas (keandalan) dilakukan setelah pengujian validitas dan hanya dilakukan terhadap pernyataan-pernyataan yang valid saja. Berdasarkan hasil pengujian validitas terdapat 27 item pernyataan yang valid, maka pernyataan tersebut dapat diuji reliabilitasnya. Berdasarkan hasil perhitungan (lampiran 3), diperoleh bahwa nilai koefisien reliabilitas adalah $\mathbf{0 , 8 6 3}$. Dengan demikian dapat dikatakan bahwa instrument penelitian ini adalah reliabel sebesar $86,3 \%$.

Pengujian ini dilakukan dengan teknik koefisien kontingensi dimana sebelumnya harus melakukan uji chi-kuadrat terlebih dahulu. Dari hasil perhitungan diperoleh harga chi kuadrat variabel $X$ adalah $\chi^{2}=20,02$. Dari tabel $\chi^{2}$, diperoleh nilai Chi Kuadrat sebesar $\chi_{(0,95)(3)}^{2}=7,815$. Ternyata $\chi^{2}$ hitung $<\chi^{2}$ tabel $(20,02>7,815)$. Berarti $\mathrm{H}_{0}$ ditolak dan $\mathrm{H}_{2}$ diterima.

Dengan demikian, dapat disimpulkan bahwa persepsi mahasiswa akuntansi mengenai lingkungan kerja eksternal auditor memiliki pengaruh yang signifikan terhadap pilihan karirnya sebagai auditor.

\section{Pembahasan Hasil Penelitian Pengaruh Persepsi Mahasiswa Mengenai Lingkungan Kerja Eksternal Auditor Terhadap Pilihan karir sebagai Auditor \\ Hasil pengolahan data dan pengujian hipotesis yang dilakukan dengan} membandingkan nilai chi kuadrat hitung dengan nilai chi kuadrat tabel menggunakan tingkat sigifikansi 0,05 diperoleh nilai chi kuadrat tabel sebesar 7,815 . Ternyata $\chi^{2}$ hitung $>\chi_{\text {tabel, }}^{2} 20,02>7,815$ hasil ini menunjukkan bahwa persepsi mahasiswa akuntansi 
mengenai lingkungan kerja eksternal auditor memiliki pengaruh yang signifikan terhadap pilihan karirnya sebagai auditor.

Dari hasil penelitian di atas yaitu persepsi mahasiswa akuntansi mengenai lingkungan kerja eksternal auditor, terdapat persepsi yang kurang positif mengenai kepastian menempati jabatan supervisor dalam 2 tahun (indikator promosi, pelatihan dan pengawasan). Persepsi yang kurang positif tersebut dapat dikaitkan dengan informasi yang negatif dari karakteristik-karakteristik tersebut yang membentuk persepsi responden yang negatif pula.

Pada indikator masalah pribadi hal yang paling menonjol adalah mengenai pernyataan masalah waktu lembur, perjalanan ke luar kota dan penugasan pekerjaan diketahui bahwa persepsi responden adalah kurang positif. Masalah waktu lembur, perjalanan ke luar kota dan penugasan pekerjaan mendapatkan persepsi yang tidak positif, persepsi tersebut dibentuk dari informasi negatif yang didapatkan oleh responden. Salah satu dari hal tersebut merupakan alasan yang paling banyak diberikan untuk meninggalkan profesi auditor.

Dari karekteristik responden diketahui bahwa hampir seluruh responden tidak memiliki pengalaman dalam bidang audit sebanyak 96\%. Dengan demikian, persepsinya mengenai lingkungan kerja eksternal auditor banyak dibentuk oleh berbagai informasi yang diperolehnya dari berbagai media, misalnya perkuliahan, dosen, teman, media massa dan sebagainya. Informasi yang tidak akurat akan mengahasilkan persepsi yang tidak akurat pula. Oleh karena itu, diperlukan suatu media yang dapat menyampaikan informasi yang benar dan akurat mengenai lingkungan kerja eksternal auditor. Pengambilan keputusan mengenai karir akan reliabel dan benar apabila individu dapat menemukan informasi yang tepat serta dapat menggunakannya dengan baik. Akan tetapi, informasi atau pengetahuan yang diperoleh bukanlah satu-satunya hal yang dapat membentuk persepsi, masih ada faktor-faktor lainnya. Jika melihat karakteristik responden, beberapa responden telah memiliki pengalaman dalam bidang audit. Hal tersebut dapat mengindikasikan bahwa selain dibentuk oleh informasi yang diperoleh, persepsi mereka mengenai lingkungan kerja eksternal auditor juga dibentuk oleh pengalamannya dalam bidang audit sewaktu magang di Kantor Akuntan Publik.

\section{Simpulan}

1) Mayoritas mahasiswa Program Studi Akuntansi Universitas Pendidikan Indonesia memiliki persepsi yang positif terhadap lingkungan kerja eksternal auditor yang mencakup indikator-indikator tugas dan tanggung jawab kerja, indikator promosi, pelatihan dan pengawasan serta indikator masalah pribadi. Persepsi mahasiswa kurang positif mengenai jenjang karir dalam KAP, masalah waktu lembur, perjalanan ke luar kota serta penugasan pekejaan dalam profesi auditor.

2) Secara keseluruhan mahasiswa Program studi Akuntansi pada Universitas Pendidikan Indonesia memilih profesi auditor sebagai karirnya setelah lulus nanti.

3) Persepsi mahasiswa akuntansi mengenai lingkungan kerja auditor memiliki pengaruh yang signifikan terhadap pilihannya untuk berkarir sebagai auditor. Disamping itu 
pula terdapat keterkaitan yang erat antara pilihan karir mahasiswa akuntansi sebagai auditor dengan persepsinya mengenai lingkungan kerja auditor.

\section{Saran}

Berdasarkan kesimpulan dan pembahasan sebelumnya, maka beberapa saran yang dapat direkomendasikan adalah:

1. Bagi Mahasiswa Akuntansi:

Mahasiswa akuntansi hendaknya terus meningkatkan wawasan pengetahuannya mengenai profesi auditor dari berbagai sumber seperti dosen, alumni, teman, dan berbagai media, tidak hanya terbatas pada pengetahuan yang telah diperoleh lewat perkuliahan di kampus. Hal ini penting untuk membentuk persepsi yang lebih akurat mengenai profesi auditor dan pemahaman yang dimiliki bertambah luas.

2. Bagi peneliti selanjutnya:

a. Mengembangkan isi dan bentuk kuesioner dengan mengevaluasi kembali indikator-indikator lingkungan kerja auditor sesuai dengan perkembangan profesi auditor yang terjadi sehingga memperoleh hasil yang lebih maksimal seperti memasukkan komponen kode etik dan etos kerja akuntan publik

b. Memperluas alternatif pilihan karir mahasiswa akuntansi pada berbagai jenis profesi akuntansi lainnya, misalnya akuntan pemerintah, akuntan manajemen, dan sebagainya, karena pilihan karir akuntansi tidak terbatas pada profesi auditor (akuntan publik) saja.

c. Perlu diteliti faktor-faktor lainnya yang diduga memiliki pengaruh terhadap pilihan karir mahasiswa akuntansi sebagai auditor.

d. Penelitian ini hanya dilakukan terhadap mahasiswa Program Studi Akuntansi pada Universitas Pendidikan Indonesia, maka penulis menyarankan agar diadakan penelitian untuk mahasiswa akuntansi di Universitas-Universitas lainnya, baik yang berbeda di wilayah Bandung maupun di kota-kota lain di seluruh Indonesia.

\section{Daftar Pustaka}

Achmad S Ruky. 2003. Sumber Daya Manusia Berkualitas Mengubah Visi menjadi Realitas.Edisi Pertama. Jakarta: PT Gramedia Pustaka Utama.

Adam I Indrawijaya. 2000. Perilaku Organisasi, Edisi Pertama. Bandung: Sinar Baru Algersido.

Agoes Dariyo. 2004. Jurnal Provitae. Jakarta: Yayasan Obor Indonesia.

Carecello, J.V.J.E., Cupeland R.H. Hermasison, dan D.H. Turner. 1991. A Public Accounting Career. The Gap Between Student Expectations and Accounting Staff Experiences. Accounting Horizons (Sept): 1-11.

Departemen Pendidikan dan Kebudayaan. 2001. Kamus Besar Bahasa Indonesia, Edisi kedua. Jakarta: Balai Pustaka.

Dewan SPAP Ikatan Akuntan Indonesia. Kompartemen Akuntan Publik. 2001. Standar Profesional Akuntan Publik per 1 Januari 2001. Jakarta: PT. Salemba Empat.

Dewa Ketut Sukardi. 1998. Bimbingan Karir di Sekolah. Jakarta: Ghalia Indonesia. 
DeZoort, F.T., A.T. Lord, dan B.R. Cargile. 1997. A Comparison of Accounting Professors' and Student Perceptions of the Public Accounting Work Environment. Issues in Accounting Education (Fall): 281-298.

Husein Umar. 2002. Metode Riset Bisnis. Jakarta: Gramedia Pustaka Utama.

Ikatan Akuntan Indonesia. 2001. Standar Professional Akuntan Publik. Jakarta: Salemba empat

Iqbal Hasan. 2002. Metodologi Penelitian dan Aplikasinya. Jakarta: Ghalia Indonesia.

Jalaludin Rakhmat. 2004. Psikologi Komunikasi, Edisi Revisi. Bandung: PT Remaja Rosdakarya.

Mulyadi. 2002. Auditing, Edisi keenam. Jakarta: PT Salemba Empat.

Mulyadi dan Kanaka Puradiredja. 1998. Auditing, Edisi Kelima. Jakarta: PT Salemba Empat.

Moh. Nazir. 2003. Metode Penelitian. Jakarta: Ghalia Indonesia.

Riduwan, Akdon. 2007. Rumus dan Data Dalam Analisis Statistika. Bandung: Alfabeta.

Sobur, Alex. 2003. Psikologi Umum. Bandung: CV. Pustaka Setia.

Sugiyono. 2003. Metode Penelitian Bisnis. Bandung: CV. Alfabeta.

Suharsimi Arikunto. 2000. Manajemen Penelitian. Jakarta: Rineka Cipta. 